\title{
Effect of corticosteroid treatment on 1376 hospitalized COVID-19 patients. A cohort study.
}

Filippo Albani ${ }^{1}$ M.D., Federica Fusina ${ }^{1}$ M.D., Enza Granato ${ }^{1}$ M.D., Cristina Capotosto ${ }^{1}$ M.D.,Claudia Ceracchi1 M.D., Riccardo Gargaruti¹ M.D., Giovanni Santangelo ${ }^{1,2}$ M.D., Luca Schiavone ${ }^{1}$ M.D., Maria Salvatrice Taranto ${ }^{1}$ B.S., Cinzia Tosati ${ }^{1}$ M.D., Elena Vavassori ${ }^{1}$ M.D., Giuseppe Natalini ${ }^{1}$ M.D.

\section{Affiliations}

1. Department of Anesthesia, Intensive Care and Pain medicine, Fondazione Poliambulanza Istituto Ospedaliero, Brescia, Italy.

2. Department of Intensive Care Medicine and Anaesthesiology, Fondazione Policlinico Universitario A. Gemelli, Università Cattolica del Sacro Cuore, Rome, Italy.

\section{Corresponding Author}

Federica Fusina, Department of Anesthesia, Intensive Care and Pain medicine, via Bissolati, 57, Brescia, 25124, IT. Email: f.fusina@gmail.com

\section{Word count}

1955 words 
medRxiv preprint doi: https://doi.org/10.1101/2020.07.17.20155994; this version posted July 18, 2020. The copyright holder for this preprint (which was not certified by peer review) is the author/funder, who has granted medRxiv a license to display the preprint in perpetuity. It is made available under a CC-BY-NC-ND 4.0 International license.

\begin{abstract}
Background: Since the start of the novel coronavirus 2019 (COVID-19) pandemic, corticosteroid use has been the subject of debate. The available evidence is uncertain, and knowledge on the subject is evolving. The aim of our cohort study was to evaluate the association between corticosteroid therapy and hospital mortality, in patients hospitalized with COVID-19 after balancing for possible confounders.
\end{abstract}

Results: One thousand four hundred forty four patients were admitted to our hospital with a positive RT-PCR test for SARS-CoV-2, 559 patients (39\%) were exposed to corticosteroids during hospital stay, $844(61 \%)$ were not exposed to corticosteroids.In the cohort of patients exposed to corticosteroids, 171 (30.6\%) died. In the cohort of patients not exposed to corticosteroids, $183(21.7 \%)$ died (unadjusted $p<0.001)$. Nonetheless, exposure to corticosteroids was not associated with in-hospital mortality after balancing with overlap weight propensity score (adjusted $p=0.25$ ). Patients in the corticosteroids cohort had reduced risk of ICU admission (adjusted $p<0.001$ ).

Conclusions: Treatment with corticosteroids did not affect hospital mortality in patients with COVID-19 after balancing for confounders. A possible advantage of corticosteroid therapy was to reduce Intensive Care Unit admission, which could be useful in reducing pressure on the Intensive Care Units in times of limited resources, as during the COVID-19 pandemic. 
medRxiv preprint doi: https://doi.org/10.1101/2020.07.17.20155994; this version posted July 18, 2020. The copyright holder for this preprint (which was not certified by peer review) is the author/funder, who has granted medRxiv a license to display the preprint in perpetuity.

\section{Introduction}

In December 2019 a cluster of atypical pneumonia was observed in Wuhan, China. A new coronavirus, later called Severe Acute Respiratory Syndrome Coronavirus 2 (SARS-CoV 2), was identified as responsible for the disease, ${ }^{1}$ which subsequently spread to the rest of the world. More than two thousand patients presented to our Emergency Department with a positive RT-PCR test for SARS-CoV 2 during the novel coronavirus disease (COVID-19) pandemic, from $20^{\text {th }}$ February to $10^{\text {th }}$ May. One thousand four hundred and forty three of them were admitted to the hospital.

Many pharmacological therapies have been attempted despite the absence of evidence supporting their efficacy, among them corticosteroids.

Initially the World Health organization discouraged the use of corticosteroids for the treatment of COVID-19 because their administration to patients with SARS had shown no survival benefit and possible harms (avascular necrosis, psychosis, diabetes, and delayed viral clearance). ${ }^{2-4}$ The interest in corticosteroids was renewed by the observation that their use was associated with a mortality reduction in COVID-19 patients in China, ${ }^{5}$ and recommendations after this report included the use of steroids in patients with COVID-19 and ARDS as a weak recommendation. ${ }^{6}$

This uncertain and evolving evidence concerning the use of corticosteroids had, as a consequence, their inconstant use in COVID-19 patients. In our hospital they were used in about $40 \%$ of patients.

Gathering evidence on the effect of corticosteroids treatment in COVID-19 is crucial, because the infection rates of other human coronaviruses have a typical wave pattern with the pick in autumnlwinter ${ }^{7}$ and a second surge of the disease could be possible.

The aim of our cohort study was to evaluate the association between corticosteroid therapy and hospital mortality in patients hospitalized with COVID-19 after balancing for possible confounders. 
medRxiv preprint doi: https://doi.org/10.1101/2020.07.17.20155994; this version posted July 18, 2020. The copyright holder for this preprint (which was not certified by peer review) is the author/funder, who has granted medRxiv a license to display the preprint in perpetuity.

\section{Methods}

The setting for this observational cohort study was a 600 bed tertiary care hospital located in Brescia (Northern Italy). Data was extracted from the electronic medical charts of consecutive patients who had been admitted during the pandemic crisis of Severe Acute Respiratory Syndrome CoronaVirus-2 (SARS-CoV-2), between February $20^{\text {th }}$ and May $10^{\text {th }}$ 2020. The study protocol was approved by the Ethical Committee of Brescia (NP-4210). All research was conducted in accordance with Declaration of Helsinki.

Clinical, demographic and laboratory data from all adult patients who were admitted to the hospital and had a positive test for SARS-CoV2 from biological material were recorded at admission. Tests were conducted with Real Time Polymerase-Chain-Reaction assay (RTPCR).

Patients younger than 18 years or with no available outcome at the time of analysis were excluded from the study. Patients were followed up until discharge.

The patients were classified into two cohorts, based on exposure to corticosteroids during hospitalization.

In-hospital mortality was the primary outcome. The rate of admission to the Intensive Care Unit was the secondary outcome. Patients were admitted in ICU if they had, during Non Invasive Ventilation: $\mathrm{PaO} / \mathrm{FiO} 2<100 \mathrm{mmHg}$, dyspnea, tachypnea (more than 40 breaths per minute), tidal volume greater than $10 \mathrm{ml} / \mathrm{kg}$.

One thousand three hundred seventy seven patients were needed to obtain a power of $85 \%$ to detect an Odds Ratio 0.72 , assuming mortality was $25 \%$ in those receiving corticosteroids, with a fraction of patients treated of $1: 3$ and alpha $=0.05^{8}$. The 12 weeks follow up ensured $97 \%$ of patients were discharged or had died by the end of the study period. Continuous variables were expressed as mean (standard deviation) or as median $\left(1^{\text {st }}, 3^{\text {rd }}\right.$ quartile) and factor variables as count (percentage). Bivariate analysis of outcome 
medRxiv preprint doi: https://doi.org/10.1101/2020.07.17.20155994; this version posted July 18, 2020. The copyright holder for this preprint (which was not certified by peer review) is the author/funder, who has granted medRxiv a license to display the preprint in perpetuity.

It is made available under a CC-BY-NC-ND 4.0 International license .

was realized on identified a priori variables with Fisher test for factorial variable and t-test and Mann-Whitney test for continuous ones.

A overlap weight propensity score for treatment allocation was estimated from a multivariable model containing patient age, sex, $\mathrm{PaO}_{2} / \mathrm{FiO}_{2}$, lactate, $\mathrm{C}$ Reactive Protein, Platelets, ICU admission and treatment with corticosteroids, enoxaparin, azithromycin or hydroxychloroquine. Dose of hydrocortisone and methylprednisolone were converted to equivalent doses of dexamethasone. ${ }^{9}$

The overlap weight propensity score was then applied to a logistic regression modelling the primary outcome (in-hospital mortality) ${ }^{10}$. Odds Ratio with 95\% Confidence Interval $(\mathrm{OR}, 95 \% \mathrm{Cl})$ are reported. The same was performed for OR of ICU admission, considering only corticosteroids treatment received on the wards. Missing values were assessed and replaced by mean substitution. If a statistical significant association was found, the Evalues for the point estimate and the confidence interval limit closer to the null were computed, to assess the possible effect of unmeasured confounder. ${ }^{11}$ Three sensitivity analyses were planned: one taking into account the quartiles of timing of hospital admission, one excluding patients admitted to intensive care, another analyzing complete cases. Significance was evaluated at $\alpha=0.05$ and all testing was 2 -sided.

Statistical analysis was performed using R Studio software version 4.0.0 (R Core Team, 2014) and packages 'psw' and 'E-value' for overlap weight propensity score and calculation of E-value. Recorded data from this cohort has been used to evaluate effect of other pharmacological intervention in COVID 19, manuscripts at present are undergoing peer-review.

\section{Results}

One thousand four hundred and forty three patients were admitted to our hospital with a positive RT-PCR test for SARS-CoV-2. Five hundred and fifty nine patients (39\%) were 
medRxiv preprint doi: https://doi.org/10.1101/2020.07.17.20155994; this version posted July 18, 2020. The copyright holder for this preprint (which was not certified by peer review) is the author/funder, who has granted medRxiv a license to display the preprint in perpetuity. It is made available under a CC-BY-NC-ND 4.0 International license .

exposed to corticosteroids during hospital stay, 844 (61\%) were not exposed to corticosteroids. Twentyseven patients were excluded from the analysis (one patient was younger than 18 years, and 26 patients were still hospitalized at the time of the analysis). Median equivalent doses of dexamethasone dose (cumulative dose/days of therapy) was $10 \mathrm{mg}$ (1st-3rd quartile 4.5-20). Patients who were never admitted to ICU received equivalent doses of dexamethasone of $8 \mathrm{mg}$ (4-16.1). Duration of corticosteroid therapy was longer in survivors than in patients who died: 6 (4-10) days vs 4 (1-7), respectively ( $p$ $<0.001)$.

Clinical and laboratory characteristics in the cohort of patients exposed and not exposed to corticosteroids are shown in Table 1. Age was not significantly different between the two cohorts, while Body Mass Index was higher in patients treated with corticosteroids. Arterial hypertension was more frequent in the corticosteroid group, while diabetes mellitus was not significantly different between the two groups. Patients in the corticosteroids cohort were more hypoxic and the inflammation markers (CRP and LDH) were higher, moreover lymphocytopenia was more severe. $\mathrm{PaCO}_{2}$ was not different in the two cohorts. One hundred seventy one patients died (30.6\%) in the cohort of patients exposed to corticosteroids, and $183(21.7 \%)$ died in the cohort of patients not exposed to corticosteroids (unadjusted $p<0.001)$. Fifty six patients $(11.5 \%)$ were admitted to ICU in the cohort of patients exposed to corticosteroids on the ward vs 131 (14.4\%) who were not treated with corticosteroids in the ward (unadjusted $p=0.15$ ).

All the recorded variables were associated with mortality in the bivariate analysis except for Body Mass Index, history of arterial hypertension or diabetes mellitus and $\mathrm{PaCO}_{2}$, as shown in Table 2.

Covariate balancing with overlap weight propensity score is shown in Figure 1 expressed as standardized mean difference which became zero after balancing. 
medRxiv preprint doi: https://doi.org/10.1101/2020.07.17.20155994; this version posted July 18, 2020. The copyright holder for this preprint (which was not certified by peer review) is the author/funder, who has granted medRxiv a license to display the preprint in perpetuity.

It is made available under a CC-BY-NC-ND 4.0 International license .

Table 3 shows that the exposure to corticosteroids was not associated with in-hospital mortality after balancing with overlap weight propensity score. Patients in the corticosteroids cohort had reduced risk of ICU admission and E-value of 2.26 (1.76 upper limit of C.I.). Planned sensitivity analyses were in agreement with these findings.

\section{Discussion}

Treatment with corticosteroids did not affect hospital mortality in patients with COVID-19 after balancing for confounders. Since their use was first proposed as a treatment strategy for ARDS, ${ }^{12,13}$ corticosteroids have been at the center of controversy in the scientific community.

Some evidence points towards a beneficial effect of corticosteroids in ARDS. ${ }^{12,14-16}$ Recently Villar et al. ${ }^{17}$ showed that early therapy with dexamethasone could reduce the duration of mechanical ventilation and the overall mortality in patients with established moderate-to-severe ARDS, possibly because early administration could have an effect on the systemic immune response involved in ARDS pathophysiology. Some evidence casts doubts on the appropriateness of corticosteroid therapy: a large multicenter randomized clinical trial ${ }^{18}$ showed no benefit in ARDS and found an increased risk of mortality when treatment began late in the course of the disease. Moreover, corticosteroid use has been associated with complications such as increased infection rate, ${ }^{19}$ hyperglycemia, ${ }^{20,21}$ hypernatremia ${ }^{22}$ and ICU acquired weakness. ${ }^{23}$

At the beginning of the COVID-19 pandemic, caution was advised when prescribing corticosteroids, due to the possibility of a more prolonged viral shredding and reduced viral clearance. ${ }^{24}$ The off-label use of steroids became increasingly popular after the first study about a possible decrease of mortality in COVID-19 ARDS with the use of corticosteroids was published. ${ }^{5}$ Nevertheless, this study suffered some relevant limitations.

Corticosteroids therapy was assessed in a small cohort of ARDS patients (84 patients), 
medRxiv preprint doi: https://doi.org/10.1101/2020.07.17.20155994; this version posted July 18, 2020. The copyright holder for this preprint (which was not certified by peer review) is the author/funder, who has granted medRxiv a license to display the preprint in perpetuity.

and 50 out of them (60\%) received methylprednisolone. More relevantly, data were shown without any balancing for possible confounders.

The crude mortality in our study was higher in patients treated with corticosteroids than in patients who did not receive them. The risk of in-hospital death did not differ between treated and non treated patients when adjusted for patients' characteristics, which were similar to the ones described in previous studies. ${ }^{25-27}$ The lack of effect of steroids on crude mortality has been previously reported in COVID-19 patients. ${ }^{28,29}$ Recently a preprint, not peer-reviewed manuscript of a randomized clinical trial (RCT) called RECOVERY trial was made available. This trial reports a $3 \%$ reduction of hospital mortality with the use of corticosteroids in COVID-19 patients. We hope that the peer reviewed results and conclusions of this study will be made available as soon as possible, so as to have a better understanding of the effects of corticosteroids in COVID-19. ${ }^{30}$ Nonetheless data from randomized clinical trials should always be compared to data from observational studies, because it might suffer from limited external validity. In many occasions, randomized trials on septic patients were not subsequently confirmed and their importance was reduced with time, including what concerned the use of steroids. ${ }^{31-34}$

A positive finding associated with the use of steroids was a reduced ICU admission rate compared to patients not receiving them. Corticosteroids can improve compliance and hypoxemia in ARDS patients, ${ }^{18}$ reducing the indication for ICU admission in our hospital during the COVID-19 pandemic, which was triggered by hypoxemia severity and dyspnea. In this sense, therapy with corticosteroids could be useful in reducing pressure on the Intensive Care Units in times of limited resources, as during the COVID-19 pandemic, when ICU bed occupancy had to be rationalized.

The impact of steroid therapy cannot be assessed without considering the used dose. In our patients the median equivalent dose of dexamethasone was $10 \mathrm{mg} / \mathrm{die}$. Recent data showed that a low dose corticosteroids, defined ad lower than $1 \mathrm{mg} \cdot \mathrm{kg}^{-1} \cdot \mathrm{day}^{-1}$ of 
medRxiv preprint doi: https://doi.org/10.1101/2020.07.17.20155994; this version posted July 18, 2020. The copyright holder for this preprint (which was not certified by peer review) is the author/funder, who has granted medRxiv a license to display the preprint in perpetuity. It is made available under a CC-BY-NC-ND 4.0 International license .

prednisone (equivalent to $0.15 \mathrm{mg} \cdot \mathrm{kg}^{-1} \cdot \mathrm{day}^{-1}$ of dexamethasone) ${ }^{9}$ had no effect on mortality, whereas higher doses were independently associated with and increase risk of death in patients with severe COVID-19. ${ }^{35}$ The weight in our patients was 77 (17) kg, which means that the average daily dose was about $0.13 \mathrm{mg} \cdot \mathrm{kg}^{-1} \cdot \mathrm{day}^{-1}$. Therefore the finding that low doses of steroids have no impact on mortality is confirmed by our data. The study suffers three main limitations. First, it is a retrospective analysis of prospectively collected data. Second, it is a single center study and the findings might be valid for centers with a similar setting and volume of COVID-19 admissions. Finally, propensity score with overlap method was used to balance covariate across the two treatment cohorts, so the effect of known covariate associated with mortality was taken into account and more robust conclusions could be drawn. ${ }^{36}$ Nevertheless the effect of unmeasured confounders or could not be excluded. In light of this limitation, meta-analyses taking into account data from this and other observational studies are needed.

In conclusion, treatment with corticosteroids was not associated with in-hospital mortality in patients admitted for COVID-19, when balancing for possible confounders. A possible advantage of corticosteroids was to reduce ICU admission, which could be useful in reducing pressure on the Intensive Care Units in times of limited resources, as during the COVID-19 pandemic. 
medRxiv preprint doi: https://doi.org/10.1101/2020.07.17.20155994; this version posted July 18,2020 . The copyright holder for this preprint (which was not certified by peer review) is the author/funder, who has granted medRxiv a license to display the preprint in perpetuity. It is made available under a CC-BY-NC-ND 4.0 International license .

\section{Data availability}

The datasets generated during and/or analysed during the current study are available from the corresponding author on reasonable request.

\section{Ethics approval and consent to participate}

The referral Ethics Committee (Comitato Etico di Brescia) approved the study and waived the need for informed consent from individual patients, due to the retrospective nature of the study. All research was conducted in accordance with Declaration of Helsinki.

\section{Consent for publication}

Not applicable. 
medRxiv preprint doi: https://doi.org/10.1101/2020.07.17.20155994; this version posted July 18, 2020. The copyright holder for this preprint (which was not certified by peer review) is the author/funder, who has granted medRxiv a license to display the preprint in perpetuity.

\section{References}

1. Wang, C., Horby, P. W., Hayden, F. G. \& Gao, G. F. A novel coronavirus outbreak of global health concern. Lancet Lond. Engl. 395, 470-473 (2020).

2. Arabi, Y. M. et al. Corticosteroid Therapy for Critically III Patients with Middle East Respiratory Syndrome. Am. J. Respir. Crit. Care Med. 197, 757-767 (2018).

3. Stockman, L. J., Bellamy, R. \& Garner, P. SARS: systematic review of treatment effects. PLoS Med. 3, e343 (2006).

4. World Health Organization. Clinical management of severe acute respiratory infection (SARI) when COVID-19 disease is suspected. Interim guidance 13 March 2020. (2020).

5. Wu, C. et al. Risk Factors Associated With Acute Respiratory Distress Syndrome and Death in Patients With Coronavirus Disease 2019 Pneumonia in Wuhan, China. JAMA Intern. Med. (2020) doi:10.1001/jamainternmed.2020.0994.

6. Alhazzani, W. et al. Surviving Sepsis Campaign: guidelines on the management of critically ill adults with Coronavirus Disease 2019 (COVID-19). Intensive Care Med. 46, 854-887 (2020).

7. Kissler, S. M., Tedijanto, C., Goldstein, E., Grad, Y. H. \& Lipsitch, M. Projecting the transmission dynamics of SARS-CoV-2 through the postpandemic period. Science 368, 860-868 (2020).

8. Hsieh, F. Y., Bloch, D. A. \& Larsen, M. D. A simple method of sample size calculation for linear and logistic regression. Stat. Med. 17, 1623-1634 (1998).

9. Schimmer, B. ACTH, Adrenal Steroids, and Pharmacology of the Adrenal Cortex. in Goodman \& Gilman's: The Pharmacological Basis of Therapeutics 1209-1235 (McGraw-Hill Education, 2011).

10. Thomas, L., Li, F. \& Pencina, M. Using Propensity Score Methods to Create Target Populations in Observational Clinical Research. JAMA (2020) doi:10.1001/jama.2019.21558.

11. VanderWeele, T. J. \& Ding, P. Sensitivity Analysis in Observational Research: Introducing the E-Value. Ann. Intern. Med. 167, 268-274 (2017).

12. Meduri, G. U. et al. Effect of Prolonged Methylprednisolone Therapy in Unresolving Acute Respiratory 
medRxiv preprint doi: https://doi.org/10.1101/2020.07.17.20155994; this version posted July 18, 2020. The copyright holder for this preprint (which was not certified by peer review) is the author/funder, who has granted medRxiv a license to display the preprint in perpetuity.

It is made available under a CC-BY-NC-ND 4.0 International license .

Distress Syndrome: A Randomized Controlled Trial. JAMA 280, 159 (1998).

13. Bernard, G. R. et al. High-Dose Corticosteroids in Patients with the Adult Respiratory Distress Syndrome. N. Engl. J. Med. 317, 1565-1570 (1987).

14. Meduri, G. U. et al. Methylprednisolone Infusion in Early Severe ARDS. Chest 131, 954-963 (2007).

15. Tongyoo, S. et al. Hydrocortisone treatment in early sepsis-associated acute respiratory distress syndrome: results of a randomized controlled trial. Crit. Care 20, 329 (2016).

16. Abdelsalam Rezk, N. \& Mohamed Ibrahim, A. Effects of methyl prednisolone in early ARDS. Egypt. J. Chest Dis. Tuberc. 62, 167-172 (2013).

17. Villar, J. et al. Dexamethasone treatment for the acute respiratory distress syndrome: a multicentre, randomised controlled trial. Lancet Respir. Med. 8, 267-276 (2020).

18. Steinberg, K. P. Efficacy and Safety of Corticosteroids for Persistent Acute Respiratory Distress Syndrome. N. Engl. J. Med. 354, 1671-1684 (2006).

19. Giacobbe, D. R. et al. Bloodstream infections in critically ill patients with COVID-19. Eur. J. Clin. Invest. e13319 (2020) doi:10.1111/eci.13319.

20. Weber-Carstens, S. et al. Impact of bolus application of low-dose hydrocortisone on glycemic control in septic shock patients. Intensive Care Med. 33, 730-733 (2007).

21. Meijvis, S. C. et al. Dexamethasone and length of hospital stay in patients with community-acquired pneumonia: a randomised, double-blind, placebo-controlled trial. The Lancet 377, 2023-2030 (2011).

22. Fang, F. et al. Association of Corticosteroid Treatment With Outcomes in Adult Patients With Sepsis: A Systematic Review and Meta-analysis. JAMA Intern. Med. 179, 213 (2019).

23. Yang, T., Li, Z., Jiang, L. \& Xi, X. Corticosteroid use and intensive care unit-acquired weakness: a systematic review and meta-analysis. Crit. Care 22, 187 (2018).

24. Ling, Y. et al. Persistence and clearance of viral RNA in 2019 novel coronavirus disease rehabilitation patients. Chin. Med. J. (Engl.) 133, 1039-1043 (2020).

25. Grasselli, G. et al. Baseline Characteristics and Outcomes of 1591 Patients Infected With SARS-CoV-2 Admitted to ICUs of the Lombardy Region, Italy. JAMA (2020) doi:10.1001/jama.2020.5394.

26. Goyal, P. et al. Clinical Characteristics of Covid-19 in New York City. N. Engl. J. Med. 382, 2372-2374 
medRxiv preprint doi: https://doi.org/10.1101/2020.07.17.20155994; this version posted July 18, 2020. The copyright holder for this preprint (which was not certified by peer review) is the author/funder, who has granted medRxiv a license to display the preprint in perpetuity. It is made available under a CC-BY-NC-ND 4.0 International license .

(2020).

27. Rosenberg, E. S. et al. Association of Treatment With Hydroxychloroquine or Azithromycin With InHospital Mortality in Patients With COVID-19 in New York State. JAMA (2020) doi:10.1001/jama.2020.8630.

28. Yang, X. et al. Clinical course and outcomes of critically ill patients with SARS-CoV-2 pneumonia in Wuhan, China: a single-centered, retrospective, observational study. Lancet Respir. Med. 8, 475-481 (2020).

29. Xu, J. et al. Clinical course and predictors of 60-day mortality in 239 critically ill patients with COVID-19: a multicenter retrospective study from Wuhan, China. Crit. Care 24, 394 (2020).

30. Horby, P. et al. Effect of Dexamethasone in Hospitalized Patients with COVID-19: Preliminary Report. http://medrxiv.org/lookup/doi/10.1101/2020.06.22.20137273 (2020) doi:10.1101/2020.06.22.20137273.

31. Annane, D. Effect of Treatment With Low Doses of Hydrocortisone and Fludrocortisone on Mortality in Patients With Septic Shock. JAMA 288, 862 (2002).

32. Rivers, E. et al. Early Goal-Directed Therapy in the Treatment of Severe Sepsis and Septic Shock. N. Engl. J. Med. 345, 1368-1377 (2001).

33. Bruyninckx, F. \& Lauwers, P. Intensive Insulin Therapy in Critically III Patients. N. Engl. J. Med. 9 (2001).

34. Bernard, G. R., Dhainaut, J.-F. \& Helterbrand, J. D. Efficacy and Safety of Recombinant Human Activated Protein C for Severe Sepsis. N. Engl. J. Med. 11 (2001).

35. Li, X. et al. Risk factors for severity and mortality in adult COVID-19 inpatients in Wuhan. J. Allergy Clin. Immunol. 146, 110-118 (2020).

36. Li, F., Morgan, K. L. \& Zaslavsky, A. M. Balancing Covariates via Propensity Score Weighting. J. Am. Stat. Assoc. 113, 390-400 (2018). 
medRxiv preprint doi: https://doi.org/10.1101/2020.07.17.20155994; this version posted July 18, 2020. The copyright holder for this preprint (which was not certified by peer review) is the author/funder, who has granted medRxiv a license to display the preprint in perpetuity. It is made available under a CC-BY-NC-ND 4.0 International license .

\section{Author contributions}

All authors contributed to the data acquisition. F.A., G.N. and F.F. drafted the manuscript. F.A. designed and supervised the study. All authors contributed substantially to editing, revising and finalizing the manuscript before submission. All the authors approved the final manuscript.

\section{Additional Information}

The study was not funded by any grants. The authors declare no competing interests. 
medRxiv preprint doi: https://doi.org/10.1101/2020.07.17.20155994; this version posted July 18,2020 . The copyright holder for this preprint (which was not certified by peer review) is the author/funder, who has granted medRxiv a license to display the preprint in perpetuity. It is made available under a CC-BY-NC-ND 4.0 International license .

Table 1

not exposed to exposed to

corticosteroids corticosteroids $p$ value

\section{Patients}

Age

Body Mass Index

Female

Arterial hypertension

Diabetes mellitus

$\mathrm{PaO}_{2}$

$\mathrm{pH}$

$\mathrm{PaCO}_{2}$

$\mathrm{PaO}_{2} / \mathrm{FiO}_{2}$

$\mathrm{HCO}_{3}$

Lactate

Leukocytes
N (\%)

years

$\mathrm{kg}^{*} \mathrm{~m}^{-2}$

N (\%)

$\mathrm{N}(\%)$

$\mathrm{N}(\%)$

$\mathrm{mmHg}$

$59.9(23.8)$

$7.47(0.06)$

$35.2(7.7)$

$\mathrm{mmHg}$

$\mathrm{mmHg}$

$269.0(75.1)$

$235.2(74.6)<0.001$

$\mathrm{mmol}^{*} \mathrm{~L}^{-1}$

$24.7(4.0)$

$1.3(1.0)$

$1.4(1.2)$

0.193

$559(40)$

$68.7(11.5) \quad 0.853$

$27.3(4.9) \quad 0.001$

$193(34.5) \quad 0.849$

$218(39.0) \quad 0.033$

$125(22.4) \quad 0.207$

$53.2(18.5)<0.001$

$7.48(0.07) \quad 0.003$

$34.8(8.5) \quad 0.356$

$24.8(3.7) \quad 0.551$

$8.0(4.1)$
$8.6(4.4) \quad 0.009$ 
medRxiv preprint doi: https://doi.org/10.1101/2020.07.17.20155994; this version posted July 18,2020 . The copyright holder for this preprint (which was not certified by peer review) is the author/funder, who has granted medRxiv a license to display the preprint in perpetuity. It is made available under a CC-BY-NC-ND 4.0 International license .

Lymphocytes

Platelets

C-reactive Protein

Lactate Dehydrogenase
$10^{9 *} \mathrm{~L}^{-1}$

$10^{9 *} \mathrm{~L}^{-1}$

$\mathrm{mg}^{*} \mathrm{~L}^{-1}$

$U^{*} \mathrm{~L}^{-1}$
$1.2(1.1)$

$196.8(91.7)$

$98.6(78.3)$

$442.6(248.6)$
$1.0(1.0)$

0.028

$203.3(93.7) \quad 0.221$

$137.8(93.1)<0.001$

$567.6(224.6)$

0.030

Demographics, comorbidities, laboratory data and outcomes of the study subjects. Factor variables are expressed as count (\%), continuous variables as mean (standard deviation) or as median (interquartile range). Fisher test was used for factorial variables and t-test and Mann-Whitney test for continuous ones. $\mathrm{BMI}$, body mass index; $\mathrm{PaO}_{2}$ partial pressure of arterial oxygen; $\mathrm{PaCO}_{2}$ partial pressure of arterial carbon dioxide; $\mathrm{PaO}_{2} / \mathrm{FiO}_{2}$, partial pressure of arterial oxygen to the fraction of inspired oxygen 
medRxiv preprint doi: https://doi.org/10.1101/2020.07.17.20155994; this version posted July 18,2020 . The copyright holder for this preprint (which was not certified by peer review) is the author/funder, who has granted medRxiv a license to display the preprint in perpetuity. It is made available under a CC-BY-NC-ND 4.0 International license.

\section{Table 2}

Survivors Non-survivors $p$ value

Age

years

$65.8(14.0)$

$76.4(9.7) \quad<0.001$

Body Mass Index

$\mathrm{kg}^{*} \mathrm{~m}^{-2} \quad 26.6(4.8) \quad 27.2(5.3) \quad 0.071$

Female

$\mathrm{N}(\%) \quad 374(36.6)$

$93(26.3)$

0.001

Arterial hypertension

$\mathrm{N}(\%) \quad 377(36.9) \quad 122(34.5)$

0.451

Diabetes mellitus

$N(\%) \quad 204(20.0)$

$85(24.0)$

0.124

$\mathrm{PaO}_{2}$

$\mathrm{mmHg} \quad 59.4(19.8) \quad 50.9(25.6) \quad<0.001$

$\mathrm{PaCO}_{2}$

$\mathrm{mmHg}$

$35.0(6.9)$

$35.0(10.2)$

0.914

$\mathrm{PaO}_{2} / \mathrm{FiO}_{2}$

$\mathrm{mmHg}$

$271.2(69.5)$

$210.3(76.8)$

$<0.001$

$\mathrm{pH}$

$7.48(0.06)$

$7.46(0.07)$

$<0.001$

$\mathrm{HCO}_{3}$

$\mathrm{mmol}^{*} \mathrm{~L}^{-1}$

$25.1(3.5)$

$23.9(4.5)$

$<0.001$

Lactate

$\mathrm{mmol}^{\star} \mathrm{L}^{-1}$

$1.2(0.7)$

$1.8(1.5)$

$<0.001$

Leukocytes

$10^{9 *} \mathrm{~L}^{-1}$

$8.0(3.7)$

$8.8(5.3)$

0.002 
medRxiv preprint doi: https://doi.org/10.1101/2020.07.17.20155994; this version posted July 18,2020 . The copyright holder for this preprint (which was not certified by peer review) is the author/funder, who has granted medRxiv a license to display the preprint in perpetuity. It is made available under a CC-BY-NC-ND 4.0 International license .
Lymphocytes
$10^{9 *} \mathrm{~L}^{-1}$
$1.2(1.0)$
$0.9(1.1) \quad<0.001$
Platelets
$10^{9 *} \mathrm{~L}^{-1} \quad 205.5(91.7)$
$181.2(87.7) \quad<0.001$
C-reactive Protein
$\mathrm{mg}^{*} \mathrm{~L}^{-1} \quad 100.8(81.8)$
$154.6(89.2)$
$<0.001$
Lactate Dehydrogenase
$U^{*} \mathrm{~L}^{-1}$
$479.7(218.4)$
$658.2(279.8)$
0.011

Demographics, comorbidities, laboratory data and outcomes of survivors and nonsurvivors. Factor variables are expressed as count (\%), continuous variables as mean (standard deviation) or as median (interquartile range). Fisher test was used for factorial variables and t-test and MannWhitney test for continuous ones. $\mathrm{BMI}$, body mass index; $\mathrm{PaO}_{2}$ partial pressure of arterial oxygen; $\mathrm{PaCO}_{2}$ partial pressure of arterial carbon dioxide; $\mathrm{PaO}_{2} / \mathrm{FiO}_{2}$, partial pressure of arterial oxygen to the fraction of inspired oxygen. 
medRxiv preprint doi: https://doi.org/10.1101/2020.07.17.20155994; this version posted July 18,2020 . The copyright holder for this preprint (which was not certified by peer review) is the author/funder, who has granted medRxiv a license to display the preprint in perpetuity. It is made available under a CC-BY-NC-ND 4.0 International license.

Table 3

unadjusted analysis $p$ value adjusted analysis $p$ value
Admitted ICU OR (95\% C.I.)
$0.77(0.55-1.07)$
0.13
$0.48(0.34-0.66)<0.001$

Odds Ratio (OR) and 95\% confidence interval are reported for logit regression, Incidence Rate Ratios (IRR) and 95\% confidence interval for Poisson regression. 
medRxiv preprint doi: https://doi.org/10.1101/2020.07.17.20155994; this version posted July 18, 2020. The copyright holder for this preprint (which was not certified by peer review) is the author/funder, who has granted medRxiv a license to display the preprint in perpetuity. It is made available under a CC-BY-NC-ND 4.0 International license .

Figure 1

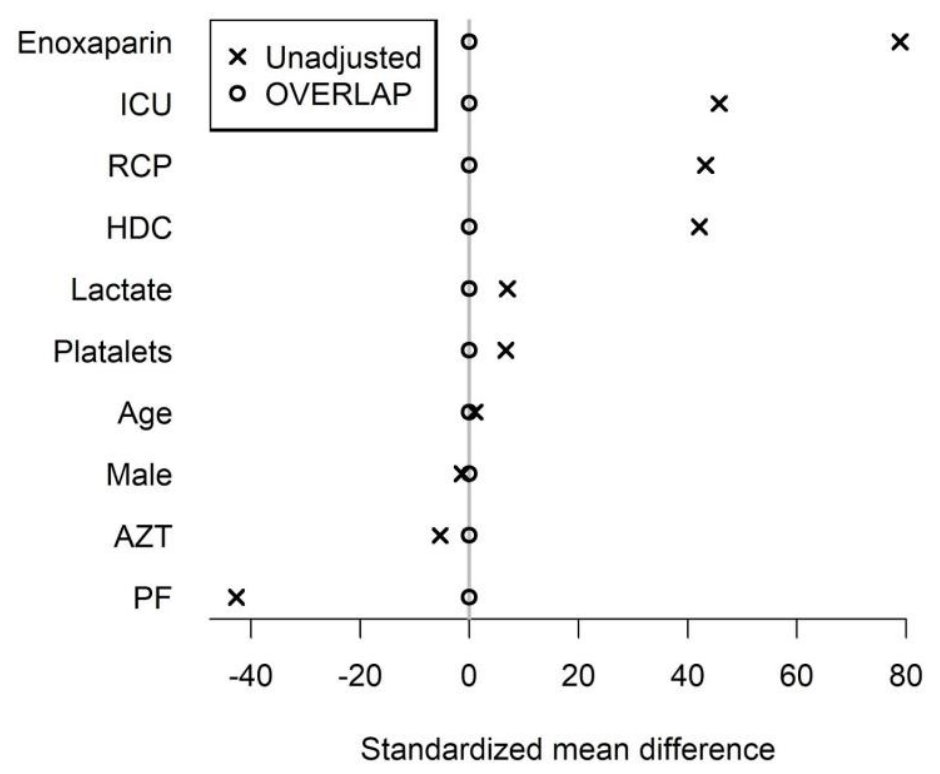

Covariance balance plot before and after overlap weights propensity matching for patients treated with corticosteroids and patients not treated with corticosteroid, expressed with standardized mean difference for comparability. ICU, Intensive Care Unit admission; RCP ,Reactive C Protein; HDC, treatment with Hydroxychloroquine; AZT, treatment with Azithromycin; $\mathrm{PF}, \mathrm{PaO}_{2} / \mathrm{FiO}_{2}$ ratio. 